ale najlepiej je określić jako „opus deuteronomicum” o potrójnym profilu literacko-teologicznym, a mianowicie historyczno-profetyczno-nomistycznym (DtrH-P-N).

Bochnia

Ks. JÓZEF ŁACH

John J. Pilch

\title{
POCZUCIE HUMORU BIBLII
}

Pewien obraz znany popularnie pod tytułem „Śmiejący się Jezus” przedstawia Pana Jezusa z głową odchyloną do tyłu i z szeroko otwartymi ustami, ukazującego w serdecznym uśmiechu doskonały komplet zębów. Paleopatolodzy na podstawie badanych przez siebie starożytnych czaszek wątpią, czy jakikolwiek dorosły człowiek tamtej kultury posiadałby tak doskonale utrzymane uzębienie zważywszy na ówczesne ogólnie słabe odżywianie i brak opieki dentystycznej. Czy jednak Pan Jezus śmiał się nawet bez tak doskonałego uzębienia? Czy śmiał się ktokolwiek w Biblii? Czy są w Biblii jakieś żarty?

\section{ŚMIECH}

Pewnych danych do zrozumienia biblijnego humoru dostarczają nam Abraham i Sara. Kiedy Bóg obiecał sędziwemu Abrahamowi syna z Sary ( $\mathrm{Rdz} 17,16-17)$, Abraham „upadł na twarz i roześmiał się" . Pierwsza część tego zdania nie opisuje rodzaju śmiechu, lecz raczej szacunek Abrahama dla Boga podczas przedstawiania kontrpropozycji: przyjmij Izmaela! Bóg odmawia i dowcipnie instruuje Abrahama, by nazwał nowego syna „śmiejący się chłopiec" (yishaq = Izaak = śmieje się). Bóg się śmieje ostatni. Podstawową zatem formą humoru w Biblii jest kalambur, gra słów.

$\mathrm{W}$ innej wersji powyższej historii, kiedy to obcy przybysze przepowiadają Abrahamowi urodzenie, a jego podsłuchującej żonie spło-

${ }^{1}$ Cytaty podane są wg Biblii Tysiąclecia - chyba, że zaznaczono inaczej \{przyp. Tł.]. 
dzenie dziecka, Sara „uśmiechnęła się do siebie” (Rdz 18, 12). Zwrot „do siebie” sugeruje, że na Bliskim Wschodzie śmianie się nie jest zwykle głośne, gromkie jak śmiech na Zachodzie. Nagłe roześmianie się może sprowadzić się do „he, he”, nigdy zaś do serdecznego „ha, ha”. Tam niemniej goście usłyszeli Sarę. Delikatność jest zatem drugim aspektem śmiechu postaci biblijnych.

Kiedy urodził się zapowiedziany chłopiec, Abraham nazwał go „Izaak”, zgodnie z Bożym poleceniem. Sara, rozważając imię chłopca przypomina sobie swój własny sceptyczny śmiech i zauważa: „Powód do śmiechu dał mi Bóg. Każdy, kto się o tym dowie, śmiać się będzie z mej przyczyny" (Rdz 21, 6).

W chwili, kiedy Izaak został odstawiony od piersi, Sara zaniepokoiła się widząc "bawiącego się" (forma hebrajskiego czasownika śmiać się; Rdz 21, 9) Izmaela. A może niepokoiło ją to, że Izmael „izaakował”, tj. śmiał się, cieszył lub może naśmiewał się, żartował, wyśmiewał Izaaka (odnośnie śmiechu jako drwiny zob. Rdz 39, 14.17)? Na to pytanie odpowiedzieć może tylko kalamburzysta. I wreszcie Abimelek, król Filistynów, patrzy przez okno i widzi Izaaka „izaakującego" z Rebeką, swą żoną, którą przedstawił królowi jako swoją siostrę (Rdz 26, 8). Słowo oznaczające „śmiech" tłumacze oddają tu zwykle jako „czułość” lub „pieszczotę”. Taki przekład ma sens, jeśli wyobrazimy sobie króla w jakimś dogodnym miejscu umożliwiającym mu patrzenie na prywatne pomieszczenie Izaaka i Rebeki. Publicznie takie zachowanie się jest niedyskretne i wstydliwe.

Ta krótka refleksja o różnych znaczeniach hebrajskiego słowa oznaczającego śmiech sugeruje kilka dalszych zagadnień do rozważenia: kalambury i gra słów, gromki śmiech, „humor alkowy”. Dla ludzi Zachodu humor biblijny wydawać się może dziwny, słaby i wcale nie śmieszny.

\section{KALAMBURY I GRA SŁÓW}

Kiedy panowie filistyńscy, którzy więzili Samsona byli pijani, wezwali swego jeńca, aby ich zabawił czy rozśmieszył (Sdz 16, 25). Samson nie był zawołanym komikiem, lecz raczej mistrzem języka. Ta umiejętność wraz z legendarną siłą były jego głównymi punktami honoru.

Swą legendarną siłą zabił tysiąc mężczyzn. Żartował na ten temat $\mathrm{w}$ kalamburze $\mathrm{z}$ hebrajskim słowem hamor oznaczającym zarówno „osła”, jak i „mnóstwo": „Szczęką osła, mnóstwo i mnóstwo"2 (wspomniane słowo hebrajskie powtórzone jest trzy razy). Następnie

${ }^{2}$ Przekład ten jest inny niż w BT. 
wyjaśnił: „Szczęką osła zabiłem tysiąc mężów” (Sdz 15, 16). Dzięki tej swojej legendarnej sile zabija Samson gołymi rękami lwa (Sdz 14, 5-9). Z imponującym dowcipem ułożył zagadkę opartą na tym, o czym on sam wiedział, że zdarzyło się z padliną:

$\mathrm{Z}$ jedzącego wyszło coś do jedzenia,

$\mathrm{Z}$ silnego wyszło coś słodkiego. (Sdz 14, 14)

Żaden przekład nie odda należycie językowych umiejętności Samsona. W języku hebrajskim zagadka ta składa się z dwóch wersetów, z których każdy dzieli się na trzy sekcje z dwoma „m” (hebrajską literą mem) starannie wkomponowanymi w każdy werset:

$\begin{array}{lll}m^{e} h a \text { okel } & \text { yașa } & \text { ma akal } \\ \text { (z jedzącego } & \text { wyszło } & \text { coś do jedzenia) } \\ \text { um } a z & \text { yașa } & \text { matoq } \\ \text { (a z silnego } & \text { wyszło } & \text { coś słodkiego) }\end{array}$

Niemożliwością byłoby odgadnąć, że Samson opisywał pszczoły i miód, który zobaczył w rozkładającej się padlinie zabitego przez siebie lwa. Nikt inny tego nie widział. Aby zwyciężyć Samsona w tej honorowej grze, trzeba było rozwiązać jego zagadkę poprzez inną zagadkę - pojedynek tu dowcipów równy doprawdy walce wręcz.

Nalegając na żonę Samsona, aby wydobyła od niego rozwiązanie, mieszkańcy miasta mieli nieco trudności w ujęciu swej odpowiedzi w znakomitszą zagadkę. Miała ona pięć liter „m” i odpowiadała dwom wersetom Samsona $(\mathrm{AB})$ w odwróconej kolejności (B'A').

\begin{tabular}{|c|c|c|}
\hline $\begin{array}{l}\text { Mah } \\
\text { (cóż }\end{array}$ & $\begin{array}{l}\text { mmatoq } \\
\text { jest słodsze }\end{array}$ & $\begin{array}{l}\text { midbas } \\
\text { nad miód?) }\end{array}$ \\
\hline $\begin{array}{l}\text { umeh } \\
\text { (i códz }\end{array}$ & $\begin{array}{l}a z \\
\text { jest silniejsze }\end{array}$ & $\begin{array}{l}\text { me ari? } \\
\text { nad lwa }\end{array}$ \\
\hline
\end{tabular}

Oczywistym rozwiązaniem tej zagadki jest miłość - odpowiedni temat na uroczystość ślubną. Samson zganił to oszustwo jeszcze jednym rymowanym kupletem. Oprócz siły miał też i rozum.

\section{JEZUS I GRA SEÓW}

Jezus demonstrował mistrzostwo językowe cytując z Tradycji (przytaczając Pismo) na miejscu i twórczo w celu odpowiedzi na jakieś pytanie lub by przekazać jakieś przesłanie (np. Łk 6, 1-5). Wy-

${ }^{3}$ j.w. 
daje się też, iż stosuje grę słów. W Mateuszowym Kazaniu na Górze (Mt 7, 6) „rada” Jezusa, aby „nie dawać [a] psom tego, co jest [b] święte; i nie rzucać [b'] pereł przed [a'] wieprze" nie brzmi zręcznie ani dowcipnie. Zdanie to opiera się na paralelizmie, lecz rzeczy święte $\mathrm{i}$ perły (b i b') nie mają się do siebie tak, jak psy i wieprze (nieczyste zwierzęta, a' i a). W języku aramejskim, którym prawdopodobnie mówił Pan Jezus, rdzeniem słowa oznaczającego rzeczy święte jest qds', które można odczytywać jako [1] qudsayya = „rzeczy święte"; albo - co jest bardziej odpowiednie w naszym przypadku [2] qadasayya = „złote pierścienie”, „kolczyki do ucha czy nosa”, „bransoletki”. Każde z tych ostatnich słów tworzy doskonałą paralelę do pereł. Oryginalny aramejski kalambur mógłby zatem wyglądać mniej więcej tak: „Nie dawajcie kalbayya (psom) waszych qadasayya (bransoletek lub rzeczy świętych) i nie rzucajcie waszych harozayya" (sznurów pereł) przed $h^{\alpha} z i r a y y a$ (wieprze)". Zwróćmy uwagę na podobne brzmienia. Ten kalambur mógł wywołać uśmiech towarzyszący ostrzeżeniu, że chrześcijanie winni być ostrożni i nie pozwalać niegodnym, aktywnym anty-chrześcijanom kontaktować się z wartościami chrześcijańskimi i wzorcami zachowań, których nie mogą docenić. (Didache 9, 5 odnosi ten werset do ograniczenia dostępu do stołu Eucharystii.)

Chociaż Piotr był rybakiem, skierowany do niego kalambur, w którym Jezus obiecał mu „Ty jesteś 'petros' (aram: Kepha, Piotr) i na tej 'petra' (aram: Kepha, skała) zbuduję mój Kościól” nie chybił prawdopodobnie celu. Ta gra słów brzmi lepiej po aramejsku, niż po grecku, a „skalisty” (Kepha) był prawdopodobnie przydomkiem Piotra już przed tym wydarzeniem. Na Bliskim Wschodzie przydomki są nie do uniknięcia, a określa je dana wspólnota. Podstawa do powyższego przydomku tkwiła być może w osobowości Piotra.

W innej dobrze znanej grze słów zarówno Jezus, jak i Nikodem (J 3,1-4) używają tego samego greckiego słowa (anothén), mającego dwa różne znaczenia: „z góry” (Jezus) i „znowu” (Nikodem). Ponieważ nie znamy aramejskiego lub hebrajskiego odpowiednika tej gry słów, może ona pochodzić raczej od Ewangelisty, niż od Jezusa.

Wszystkie powyższe kalambury wywołują humor bardzo delikatny. Gra słów wywoła uśmiech, ale nigdy wybuch śmiechu czy gromki śmiech. Czy Starożytni w ogóle śmiali się głośno?

\section{GROMKI ŚMIECH}

Niektórzy uczeni twierdzą, że Księga Estery jest biblijną księgą żartów. Rozpoczynająca ją scena trwającej 180 dni uczty wydanej przez króla Aswerusa (Kserksesa I [485-444 p.n.e.]) dla elit i oraz 
następujący po niej siedmiodniowy bankiet dla mieszkańców stołecznego miasta to pierwszy żart. Uczta sześciomiesięczna?

Po odprawieniu nieposłusznej żony Aswerus poszukuje jej następczyni. Każda ewentualna przyszła żona przygotowuje się przez dwanaście miesięcy na okoliczność sprawienia królowi przyjemności podczas spotkania trwającego jedną noc - sześć miesięcy używając olejku mirry, a sześć miesięcy wonności i maści. Zwycięża Estera. Dla nas to przykład wybujałego życia seksualnego, dla starożytnych zaś cała historia przedstawiała godną wyśmiania głupotę.

Haman proponuje królowi nagrodę, którą - jak sądzi - król zechce obdarzyć jego. Król nakazuje Hamanowi, by osobiście oddał cześć swemu znienawidzonemu wrogowi, Mardocheuszowi. Haman prowadzi wokół miasta - ku podziwowi wszystkich - zasiadającego na rumaku i ubranego w szaty królewskie Mardocheusza, wygłaszając jednocześnie pochwały na jego cześć. Jeśli Żydzi śmieją się z Hamana, dla niego samego i dla jego przyjaciół zdarzenie to nie jest bynajmniej śmieszne.

Kiedy zaś Estera odkrywa niecny spisek Hamana mający na celu zabicie wszystkich Żydów, wzburzony Aswerus wychodzi z gniewem z komnaty po to tylko, aby powróciwszy znaleźć Hamana błagającego Esterę o litość, co zostaje postrzeżone przez króla jako próba uwiedzenia królowej. Ta humorystyczna scena kończy się egzekucją Hamana na szubienicy, którą on sam przygotował dla Mardocheusza i jego rodaków. Ta Księga jest przeglądem humoru wisielczego, humoru cudzym kosztem.

Także w Ewangelii, u Pana Jezusa można dostrzec oznaki tego, co współcześni czytelnicy mogliby utożsamić z materiałem godnym wytrawnego komediopisarza. Wyobraźmy sobie, co z belką i drzazgą w oku mógłby zrobić Seinfeld (Mt 7, 1-5):

George: Jerry, przykro mi, że ci to mówię, ale masz drzazgę w oku.

Jerry: Ja? Drzazgę? Mówisz to poważnie?

George (uśmiechając się z satysfakcją): Mhm! Drzazgę.

Jerry: Nie mogę sobie wyobrazić, jak możesz widzieć moją drzazgę.

George: Wzrokiem o prawidłowej ostrości 20 na 20 - i już.

Jerry: George, twoja prawidłowa ostrość wzroku jest zablokowana przez belkę. Masz belkę w oku. Jak możesz cokolwiek widzieć?

George: Belkę? O, nie. Masz ci los - to koniec. Ale wstyd!

Niektórzy uczeni sugerują, że w tym epizodzie Pan Jezus mówi być może ze swego doświadczenia cieśli - był przecież zapewne obeznany z drzazgami, belkami i związanymi $\mathrm{z}$ tym zagrożeniami. Podobny scenariusz można sobie wyobrazić dla Jego innych podobnie przesadnych porównań: wielbłąd i ucho igielne (Mk 10, 25); przece- 
dzanie komara a połykanie wielbłąda (Mt 33, 24); mycie kubka na zewnątrz przy pozostawieniu brudnego wnętrza (Mt 23, 25).

\section{HUMOR „ALKOWY”}

Anachronizmem jest zastosowanie zwrotu humor „alkowy” do czasów i wydarzeń biblijnych, aczkolwiek opisuje on pojawiający się na kartach Biblii pewien typ humoru, mogący łatwo wywołać gromki śmiech. Niektórzy nazywają to humorem nieprzyzwoitym (obscenicznym lub graniczącym z obscenicznym).

W czasach Sędziów lud Izraela został pokonany przez króla Moabu, Eglona i dostał się pod jego okupację. Imię tego króla wywodzi się z hebrajskiego słowa, które obejmuje swym polem semantycznym takie znaczenie, jak okrągły, krąg oraz wołowy. Aby czytelnik nie stracił pointy, narrator wyjaśnia: „Eglon był bardzo otyły” ( $\mathrm{Sdz} 3$, 17). Otyłość sama w sobie nie jest powodem do śmiechu. Gromki śmiech wywołuje dopiero to, co ma miejsce potem.

Pan pobudza człowieka leworęcznego, Ehuda, aby wybawił Izraela od Eglona. Ehud sporządził miecz o dwóch ostrzach (dosłownie „dwu-usty") na jeden łokieć długi i przymocowuje go sobie pod ubraniem do prawego boku. Następnie kłania się Eglonowi mówiąc: „Królu, mam ci coś powiedzieć w tajemnicy”. Wiedząc, jak wielką wartość w tamtej kulturze przywiązywano do tajemnicy, można docenić skwapliwą chęć króla, aby tajemnicę tę usłyszeć: odsyła wszystkich. Ehud zaś zbliżył się i powiedział: „Mam dla ciebie królu słowo [lub rzecz] od Boga" i tym samym jego lewa ręka wpycha miecz w brzuch Eglona. Za ostrzem wchodzi rękojeść, kryjąc się pod powłoką tłuszczu. Na zewnątrz wysączają się „nieczystości” (fekalia). Widząc:, że umiera, Eglon udał się na ganek i zamknął się w nim. Ehud uciekł.

Kiedy słudzy Eglona powrócili, zobaczyli zamknięte drzwi i poczuli wiadomą woń. Pomyśleli: „Z pewnością chce sobie okryć nogi w letniej komnacie". Po dłuższej chwili otworzywszy jednak drzwi znaleźli go martwego.

Oprócz tego humorystycznego sposobu, w jaki został zgładzony ten znienawidzony wróg, leworęczny napastnik zwiększa ten humor. $\mathrm{Na}$ Bliskim Wschodzie lewa ręka jest używana wyłącznie do funkcji toaletowych. W benińskim języku Aja (Afryka Zachodnia) słowo oznaczające lewą rękę znaczy dosłownie „wypchnąc ręką ekskrementy na zewnątrz". Leworęczny Jehud był doskonałym wybawicielem od człowieka uważanego za „plugawego”.

Przypowieść zaś Pana Jezusa o nieurodzajnym drzewie figowym (Łk 13, 6-9) nie jest radą dla wzrastających drzew, lecz politycznym komentarzem odnoszącym się do błądzących przywódców wspólnoty 
narodu. Wyobraźmy sobie reakcję słuchaczy, kiedy ogrodnik błaga właściciela, by dać drzewu jeszcze jedną szansę i obłożyć je nawozem. To jest dokładnie to, co chłopi zrobili by z tymi ... przywódcami! Jezus ma ziemskie poczucie humoru.

\section{WNIOSEK}

Podczas swego radiowego show Garrison Kelly zauważył pewnego razu: „Faktycznie, Bóg pisze wiele dobrych komedii. Problem w tym, że musi się zmagać z tak wielu złymi aktorami, którzy nie wiedzą jak śmiesznie grać". Najlepsza droga by zrozumieć humor Biblii to uświadomienie sobie, że jest on śmieszny bardziej na sposób bliskowschodni, niż amerykański.

Dr John J. Pilch z Catonsville, w stanie Maryland, jest wykładowca studiów biblijnych na Uniwersytecie Georgetown w Waszyngtonie i autorem książki The Cultural World of Jesus Sunday, Cycle A (The Liturgical Press) oraz bestsellera Introduction to the Cultural Context of the Old and New Testaments (2 tomy, Paulists Press). Urodzony w Nowym Jorku (Brooklyn), jest pochodzenia polskiego. Zna język polski, którego nauczyli go rodzice. Od $1963 \mathrm{r}$. robi streszczenia artykułów z RBL i z innych polskich czasopism dla „New Testament Abstracts” i „Old Testament Abstracts". Tłumaczony artykuł ukazal się pt. The Bible's Sense of Humor, [w:] „The Bible Today”, vol. 33, nr 6, November 1995.

tlum. Bernard Sawicki, OSB, Tyniec

\begin{tabular}{lllllllllllll}
$S$ & $P$ & $R$ & $A$ & $W$ & $O$ & $Z$ & $D$ & $A$ & $N$ & $I$ & $A$ \\
\hline
\end{tabular}

Ks. Bernard Wodecki, SVD

\section{MIĘDZYNARODOWY KONGRES W JEROZOLIMIE Z OKAZJI 3000-LECIA JEROZOLIMY JAKO STOLICY (1996)}

Triennium 1995-1997, to uroczyste obchody jubileuszu trzech tysiącleci Miasta Świętego. Całe państwo Izrael, a zwłaszcza jego historyczna Stolica czci wszechstronnie wielką rocznicę niezmiernie doniosłego faktu dziejowe- 